\title{
OCTA-SUBSTITUTED Co(II) AND Mn(II) PHTHALOCYANINES CONTAINING BUTYL-4-HYDROXYBENZOATE GROUPS: SYNTHESIS, CHARACTERIZATION, AGGREGATION, AND INVESTIGATION OF THEIR ANTI-MICROBIAL AND ANTI-FUNGAL ACTIVITY PROPERTIES**
}

\author{
Meltem B. SAGLAM* \\ Department of Chemistry, Faculty of Science, Karadeniz Technical University, Trabzon, Turkey
}

Received January 8, 2020

We have reported, the synthesis, characterization, aggregation, and investigation of anti-microbial and anti-fungal activity properties of new octasubstituted metallophthalocyanine compounds containing dibutyl 4,4'-[(1,2-phenylene)bis(oxy)dibenzoate)]2,3dicarbonitrile units. $\mathrm{CoPc}$ and $\mathrm{MnPc}$ were synthesized by the cyclotetramerization of dinitrile with anhydrous $\mathrm{CoCl}_{2}$ or $\mathrm{Mn}(\mathrm{OAc})_{2}$. Eight bacteria and one fungus were used to test antimicrobial activities of the newly synthesized $\mathrm{CoPc}$ and $\mathrm{MnPc}$ compounds. MnPc has two times effective than the compound $\mathrm{CoPc}$ for against bacteria and fungus. MnPc showed antifungal activity against Candida albicans. It has been previously proved in the literature that the isoindole ring in the structure of the compounds play an important role in antimicrobial activity.

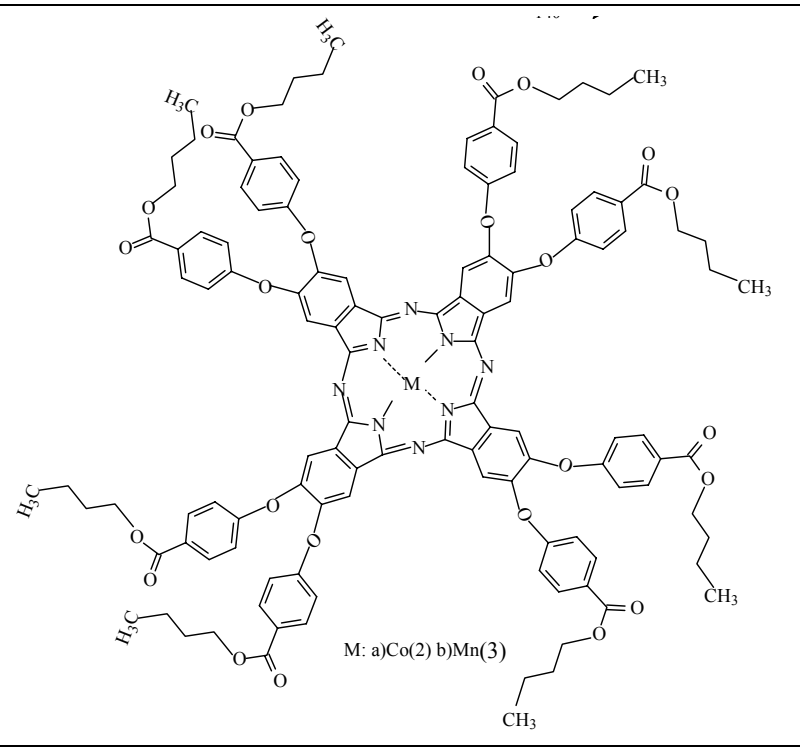

\section{INTRODUCTION}

Since the discovery of phthalocyanines, big developments have been achieved with their widespread applications. ${ }^{1-5}$ Phthalocyanines are extensively used in different fields such as solar cells, ${ }^{6,7}$ photodynamic therapy (PDT), ${ }^{8}$ liquid crystals, ${ }^{9}$ chemical sensors, ${ }^{10}$ laser dyes, ${ }^{11}$ gas sensors, ${ }^{12}$ dyes and pigments, ${ }^{13}$ catalysis. ${ }^{15}$

The practicability of Pc compounds in different technological areas strongly depends on both their solubility and electron transfer properties. On the other hand, these properties are directly related to $\pi-\pi$ interaction between the Pc molecules, which affects aggregation and solubility leanings in most organic solvents. Strong intermolecular $\pi-\pi$ interactions between the MPc molecules lead to their stacking as aggregation and thus, decrease in solubility. ${ }^{16}$ Therefore, the solubility of Pcs can be raised by the addition of appropriate functional groups, such as: alkyl, alkoxyl, phenoxyl or other bulky groups due to their substitutional positions,

\footnotetext{
* Corresponding authors: meltemkilicaslan@hotmail.com

${ }^{* *}$ Supplementary information on http://web.icf.ro/rrch/ or http://revroum.lew.ro/
} 
as a result of the decrease in the intermolecular interactions. ${ }^{17-19}$ Aggregation can cause unwanted effects arising from stacking of molecules, thus diminishing the solubility in organic solvents and water and decreasing other optical required properties needed for photodynamic therapy or other related applications. The extent of aggregation depends on various factors, such as, type of solvent, concentration of solution, nature of the substituents, type of metal in the central cavity, and temperature. Aggregation can be usually detected by the splitting or broadening of the $\mathrm{Q}$ band absorption. Nonaggregated phthalocyanines have important significance for researchers. Because aggregation can cause unwanted effects arising from stacking of molecules such as, for photodynamic therapy and other related applications. $^{21,22}$

Nowadays, the resistance of bacteria and fungi to antimicrobial agents leads scientists to work on the development of new agents. ${ }^{23}$ As it is known, phthalocyanines is becoming increasingly common in the treatment of infectious diseases. ${ }^{24}$ Therefore, the production of novel phthalocyanine compounds which are effective for the treatment of diseases is also seen as a need. The new phthalocyanine compounds synthesized in the present study have been tested against various bacteria and candida albicans.

\section{EXPERIMENTAL}

\section{Materials}

Butyl-4-hydroxybenzoate and 4,5-dichloro-1,2-dicyanobenzene were brought from commercial providers. All solvents were dried and purified as described in literature. ${ }^{25}$ The elemental analyses were performed on a Costech ECS 4010 Elemental Analyzer. The absorption spectra of the solutions were recorded using a UV mini-1240 UV- Spectrophotometer. ${ }^{1} \mathrm{H}$ and ${ }^{13} \mathrm{C}-\mathrm{NMR}$ spectra were recorded on a Bruker AVANCE III $400 \mathrm{MHz}$ NMR Spectrometer in $\mathrm{CDCl}_{3}$, and chemical shifts were reported $(\delta)$ relative to $\mathrm{Me}_{4} \mathrm{Si}$ as an internal standard. The IR spectra were recorded on a Perkin Elmer 1600 FT-IR Spectrophotometer. Mass spectra were measured on a Micromass Quattro LC/ULTIMA Spectrometer.

\section{Synthesis}

2.1. Synthesis of compound dibutyl4,4'-I(1,2phenylene)bis(oxy)dibenzoate)]2,3-dicarbonitrile (1)

Butyl-4-hydroxybenzoate $(1.27 \mathrm{~g}, 6.54 \mathrm{mmol}), 4,5-$ dichloro-1,2-dicyanobenzene $(0.64 \mathrm{~g}, 3.37 \mathrm{mmol})$ and $20 \mathrm{~mL}$ dry DMF were stirred for $15 \mathrm{~min}$. at $25^{\circ} \mathrm{C}$ and dry $\mathrm{K}_{2} \mathrm{CO}_{3}$ $(1.83 \mathrm{~g}, 13.1 \mathrm{mmol})$ was added portion-wise for $2 \mathrm{~h}$. The reaction mixture was stirred under nitrogen atmosphere at 70 ${ }^{\circ} \mathrm{C}$ for $3 \mathrm{~d}$. Then, it was emptied into ice-water and extracted with chloroform. The brown oily product was obtained. Yield: $1.48 \mathrm{mg}, 88 \%$. Anal. calcd. for $\mathrm{C}_{30} \mathrm{H}_{28} \mathrm{O}_{6} \mathrm{~N}_{2}: \mathrm{C}, 70.30 ; \mathrm{H}$, 5.51, N;5.47\%. Found: C, 70.27; H, 5.55\%, N; 5.52. IR, $v_{\max / \mathrm{cm}^{-1}}$ : 3040 (Ar-CH), 2956-2871 (Aliph.,-CH), 2229
$(\mathrm{C} \equiv \mathrm{N}), 1606(\mathrm{C}=\mathrm{O}), 1162-1073\left(-\mathrm{OCH}_{2}\right), 769 .{ }^{1} \mathrm{H}-\mathrm{NMR}$ $\left(\mathrm{CDCl}_{3}\right),(\delta: \mathrm{ppm}): 8.09 \mathrm{t}(4 \mathrm{H}, \mathrm{ArH}), 7.38 \mathrm{~s}(1 \mathrm{H}, \mathrm{ArH}), 7.28 \mathrm{~s}$ $(2 \mathrm{H}, \mathrm{ArH}), 7.05 \mathrm{~d}(3 \mathrm{H}, \mathrm{ArH}), 4.34 \mathrm{~s}\left(4 \mathrm{H}, \mathrm{O}-\mathrm{CH}_{2}\right), 1.76 \mathrm{~d}$ (4H, Aliph-H), $1.49 \mathrm{~d}\left(4 \mathrm{H}\right.$, Aliph-H), $1.00 \mathrm{t}\left(4 \mathrm{H},-\mathrm{CH}_{3}\right) .{ }^{13} \mathrm{C}-$ NMR $\left(\mathrm{CDCl}_{3}\right),(\delta: \mathrm{ppm}): 165.51,158.05,132.18,127.81$, 124.34, 118.49, $114.49(\mathrm{C} \equiv \mathrm{N}), 65.15,31.25,19.25,13.74 . \mathrm{MS}$ (FAB) $(\mathrm{m} / \mathrm{z}): 513[\mathrm{M}+\mathrm{H}]^{+}$.

\subsection{The procedure of metallophthalocyanines (MPcs)}

Dibutyl 4,4'-[(4,5-dicyano-1,2-phenylene)bis(oxy)]dibenzoate (1) $(0.24 \mathrm{~g}, 0.48 \mathrm{mmol})$, anhydrous $\mathrm{CoCl}_{2}$ or $\mathrm{Mn}(\mathrm{OAc})_{2}$ $(0.32 \mathrm{mmol})$, n-pentanol $(3 \mathrm{~mL})$ and $0.05 \mathrm{~mL} \mathrm{1,8-diaza}$ bicyclo[5.4.0] undec-7-ene (DBU) were stirred under inert atmosphere at $140{ }^{\circ} \mathrm{C}$ for $12 \mathrm{~h}$.

2.2.1. 2,3,9,16,17,23,24-Octa[dibutyl4,4'-[1,2-phenylene)bis (oxy)]dibenzoate]phthalociyaninato cobalt(II), (2):

Compound $\mathbf{2}$ was purified with column chromatography by alumina, using chloroform/ethyl acetate (2:1) solvent system. Yield: $76 \mathrm{mg}, 30 \%$ m.p: $>300{ }^{\circ} \mathrm{C}$. Anal. calcd. for $\mathrm{C}_{120} \mathrm{H}_{112} \mathrm{O}_{24} \mathrm{~N}_{8} \mathrm{Co}$ : C, 68.34; H, 5.31, N; 5.31\%. Found: C, 68.29; H, 5.33, N; $5.28 \%$. FTIR, $v_{\max / \mathrm{cm}^{-1}}$ : 3067(Ar-CH), 2956-2857(Aliph., -CH), 1714(C=O), 1270 (Ar-O-Ar), 1097 $\left(-\mathrm{OCH}_{2}\right), 769$. UV-vis (chloroform): $\lambda_{\max / \mathrm{nm}}: 668(4.13), 606$ (3.57), 329 (4.0). MS (MALDI-TOF) (m/z): $2107[\mathrm{M}]^{+}$.

2.2.2. 2,3,9,16,17,23,24-Octa/dibutyl4,4'-[1,2-phenylene)bis (oxy)]dibenzoate]phthalociyaninato manganese (II), (3):

Compound $\mathbf{3}$ was purified with column chromatography by alumina, using chloroform/petroleum benzine (20:7) solvent system. Yield: $71 \mathrm{mg}, 28 \%$, m.p: $>300^{\circ} \mathrm{C}$. Anal. calcd. for $\mathrm{C}_{120} \mathrm{H}_{122} \mathrm{O}_{24} \mathrm{~N}_{8} \mathrm{Mn}$ : C, 68.47; H, 5.32, N; $5.32 \%$. Found: $\mathrm{C}$, 68.40 ; H, 5.28, N; $5.27 \%$. FTIR, $v_{\max / \mathrm{cm}^{-1}}$ : 3068(Ar-CH), 29552850 (Aliph., $-\mathrm{CH}), 1714(\mathrm{C}=\mathrm{O}), 1265$ (Ar-O-Ar), 1081(-OCH $)_{2}$, 765. UV-vis (chloroform): $\lambda_{\max / \mathrm{nm}}: 725(4.13), 654$ (3.46), 383 (3.78). MS (MALDI-TOF) (m/z): $2139\left[\mathrm{M}+2 \mathrm{H}_{2} \mathrm{O}\right]^{+}$.

\section{Anti-microbial and Anti-fungal Activity}

Minimal inhibitory concentration assay (MIC, $\mu \mathrm{g} / \mathrm{mL}$ ) was conducted to scan the susceptibility of some bacterial strains to the newly synthesized compounds. ${ }^{26,27}$ The MIC assays for bacteria were done in LB medium at $\mathrm{pH}$ 7.2. Dimethyl sulfoxide (DMSO) was used to dissolve the compounds to prepare stock solutions. The dilution series of the chemical compounds to be tested were prepared from 7800 to $3.8 \mu \mathrm{g} / \mathrm{mL}$ concentrations in $100 \mu \mathrm{L}$ medium. The incubation of the broth cultures was performed at $37.0 \pm 1{ }^{\circ} \mathrm{C}$ for $18-24 \mathrm{~h}$. DMSO was used as, solvent control while LB medium with or without antibiotic, ampicillin, were used as positive and negative controls, respectively. MIC was accepted as the last well in the 96 cell well plate in which no growth was determined based on turbidity.

Three of Gram-positive bacterial strains, namely Bacillus subtilis ATCC 6633, Staphylococcus aureus ATCC 25923, and Streptococcus pyogenes ATCC 19615, five of Gramnegative bacterial strains which were Escherichia coli ATCC 25922, Pseudomonas aeruginosa ATCC 27853, Salmonella typhymirium ATCC 14028, Yersinia pseudotuberculosis ATCC 911, and Proteus vulgaris ATCC 13315, and also a fungus, Candida albicans ATCC 10231 were used to determine the $\mathrm{MIC}^{28}$ Bacteria were grown in Luria broth medium (containing $1 \%$ tryptone, $0.5 \%$ yeast extract, $0.5 \%$ sodium chloride, $\mathrm{pH} 7.2$ ) at $37^{\circ} \mathrm{C}$ for $18-24$ h. C. albicans was cultured in brain heart infusion (BHI, Difco Laboratories, Detroit, MI, USA) broth at $37^{\circ} \mathrm{C}$ for $24 \mathrm{~h}$ aerobically with shaking. Positive control in the case of $C$. albicans was Amphotericin B dissolved in 50\% DMSO. The optical density of the bacteria from a mid-log phase of growth was measured 
at $600 \mathrm{~nm}$ and diluted in the fresh medium to get a $5 \times 10^{5}$ $\mathrm{CFU} / \mathrm{mL}$.

\section{Aggregation studies}

Aggregation of phthalocyanines is a fact of phthalocyanine chemistry. Aggregation relies on some behaviors of metal phthalocyanines for ex.; different concentrations, solvent kind, properties of substituents, metal ion and temperature. ${ }^{29,30}$ Aggregation appears when the intermolecular gravitation force between phthalocyanine molecules is powerful than Pcsolvent union, and if molecules aggregate, new absorption bands appear. ${ }^{31}$

The aggregation behaviors of $\mathbf{2}$ and $\mathbf{3}$ were searched by their UV-vis spectra recorded at different concentrations (was changed from $12 \times 10^{-6}-2 \times 10^{-6} \mathrm{M}$ ) and at different solvents; such as; DMF, DMSO, ethyl acetate, chloroform, THF, toluene by UV-Vis Spectrophotometer. The Q band position changed with the solvent and the redshift of the Q band increased with the refractive index of the solvent.

\section{RESULTS AND DISCUSSION}

Dibutyl4,4'-[(1,2-phenylene)bis(oxy) dibenzoate)]2,3-dicarbonitrile (1) was successfully synthesized described in the literature. ${ }^{32}$

The phthalocyanines $\mathrm{CoPc}$ (2) and $\mathrm{MnPc}$ (3) accomplished by nucleophilic aromatic substutition reaction of dinitrile compound (1) with anhydrous $\mathrm{CoCl}_{2}$ and anhydrous $\mathrm{Mn}(\mathrm{acac})_{2}$ were mixed under $\mathrm{N}_{2}$ atmosphere in n-penthanol and $\mathrm{DBU}$ at $140^{\circ} \mathrm{C}$ for $18 \mathrm{~h}$. These new synthesized phthalocyanines $\mathbf{2}$ and $\mathbf{3}$ are showed enhanced solubility in organic solvents, for exp; acetone, chloroform, DMF, THF, ethyl acetate.

The synthetic pathways for the preparation of $\mathbf{1}$, CoPc (2) and MnPc (3) are shown in Scheme 1.<smiles>CCCCOC(=O)c1ccc(O)cc1</smiles>

butyl-4-hydroxybenzoate<smiles>N#Cc1cc(Cl)c(Cl)cc1C#N</smiles>

4,5- dichlorophthalonitrile<smiles>C#CCCCOC(=O)c1ccc(Oc2cc(C#N)c(C#N)cc2Oc2ccc(C(=O)OCCCC)cc2)cc1</smiles>

dibutyl 4,4'-[(4,5-dicyano-1,2-phenylene)bis(oxy)]dibenzoate

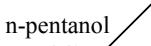

$140{ }^{\circ} \mathrm{C}$

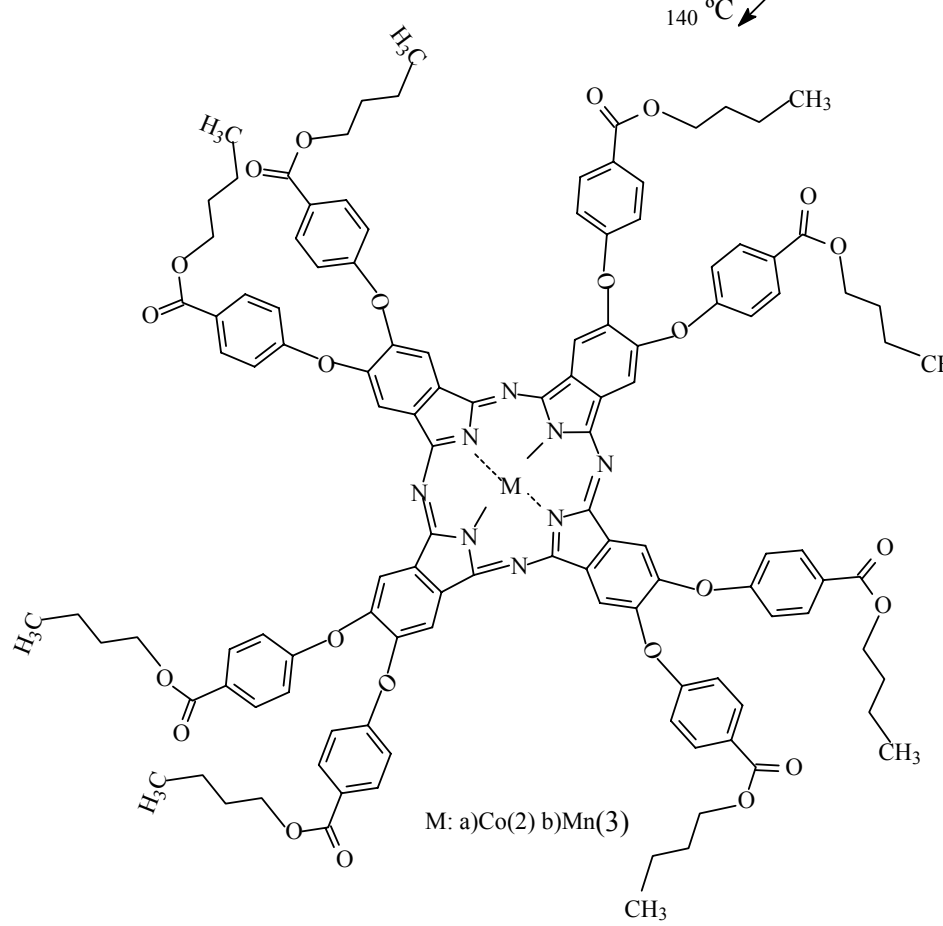

Scheme 1 - The synthesis of compounds 1-3. 


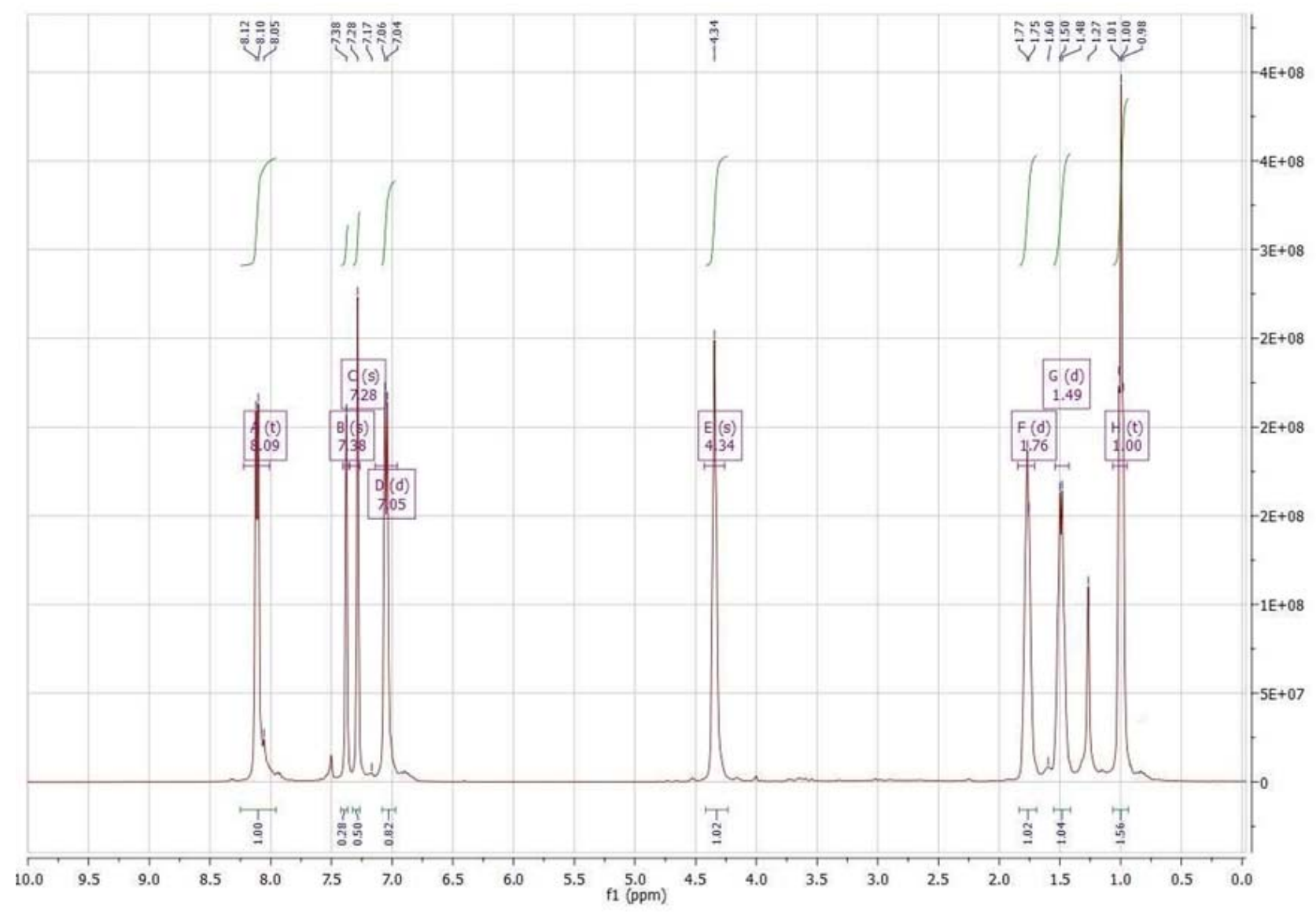

Fig. 1 - Dibutyl 4,4'-[(4,5-dicyano-1,2-phenylene)bis(oxy)]dibenzoate (1) ${ }^{1} \mathrm{H}-\mathrm{NMR}$ Spectrum.

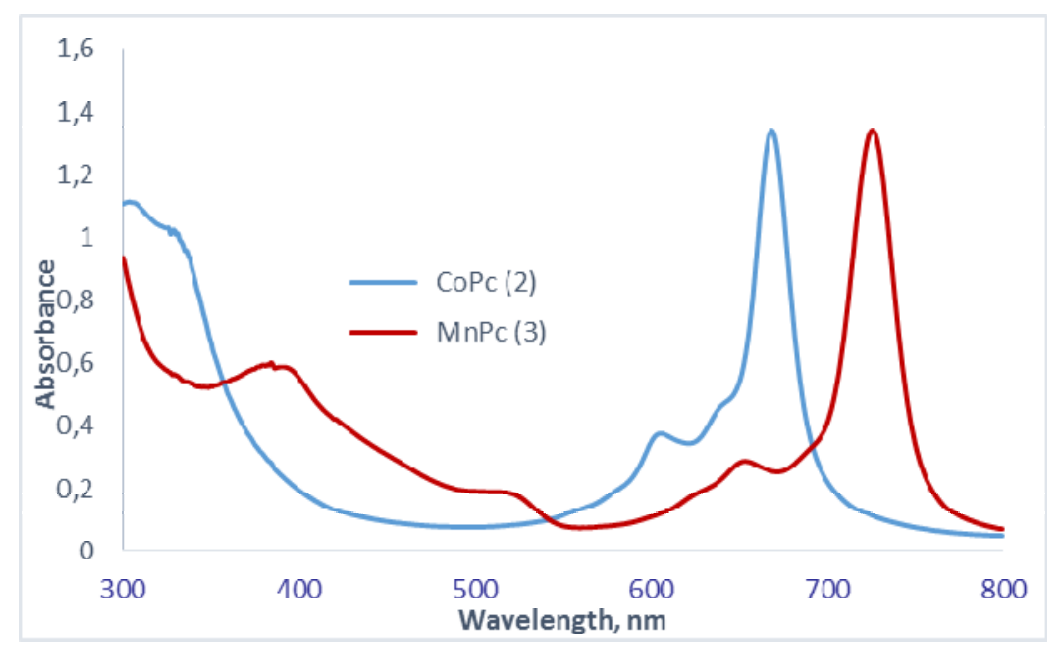

Fig. $2-\mathrm{UV} /$ Vis spectra of phthalocyanines 2,3 in chloroform $\left(1 \times 10^{-4} \mathrm{M}\right)$.

The stretching vibrations of $\mathrm{C} \equiv \mathrm{N}$ groups at $2229 \mathrm{~cm}^{-1}$ were observed in the IR spectrum of $\mathbf{1}$. In addition, the ${ }^{1} \mathrm{H}-\mathrm{NMR}$ spectrum of $\mathbf{1}$ indicated aromatic protons at 8.09, 7.38, 7.28, 7.05 ppm and aliphatic protons at $4.34,1.76,1.49,1.00 \mathrm{ppm}$ (Fig. 1). The formation of nitrile carbon atoms $(\mathrm{C} \equiv \mathrm{N})$ in $\mathbf{1}$ was defined by the signal at 118.49 ppm in its ${ }^{13} \mathrm{C}$-NMR spectrum.
The phthalocyanines $\mathbf{2}$ and $\mathbf{3}$ accomplished by nucleophilic aromatic substitution reaction of dinitrile compound 1 with anhydrous $\mathrm{CoCl}_{2}$ and anhydrous $\mathrm{Mn}(\mathrm{acac})_{2}$ were mixed under $\mathrm{N}_{2}$ atmosphere in npenthanol and DBU at $140^{\circ} \mathrm{C}$ for $18 \mathrm{~h}$. These newly synthesized phthalocyanines $\mathbf{2}$ and $\mathbf{3}$ are shown enhanced solubility in organic solvents, for exp; acetone, chloroform, DMF, THF, ethyl acetate. 

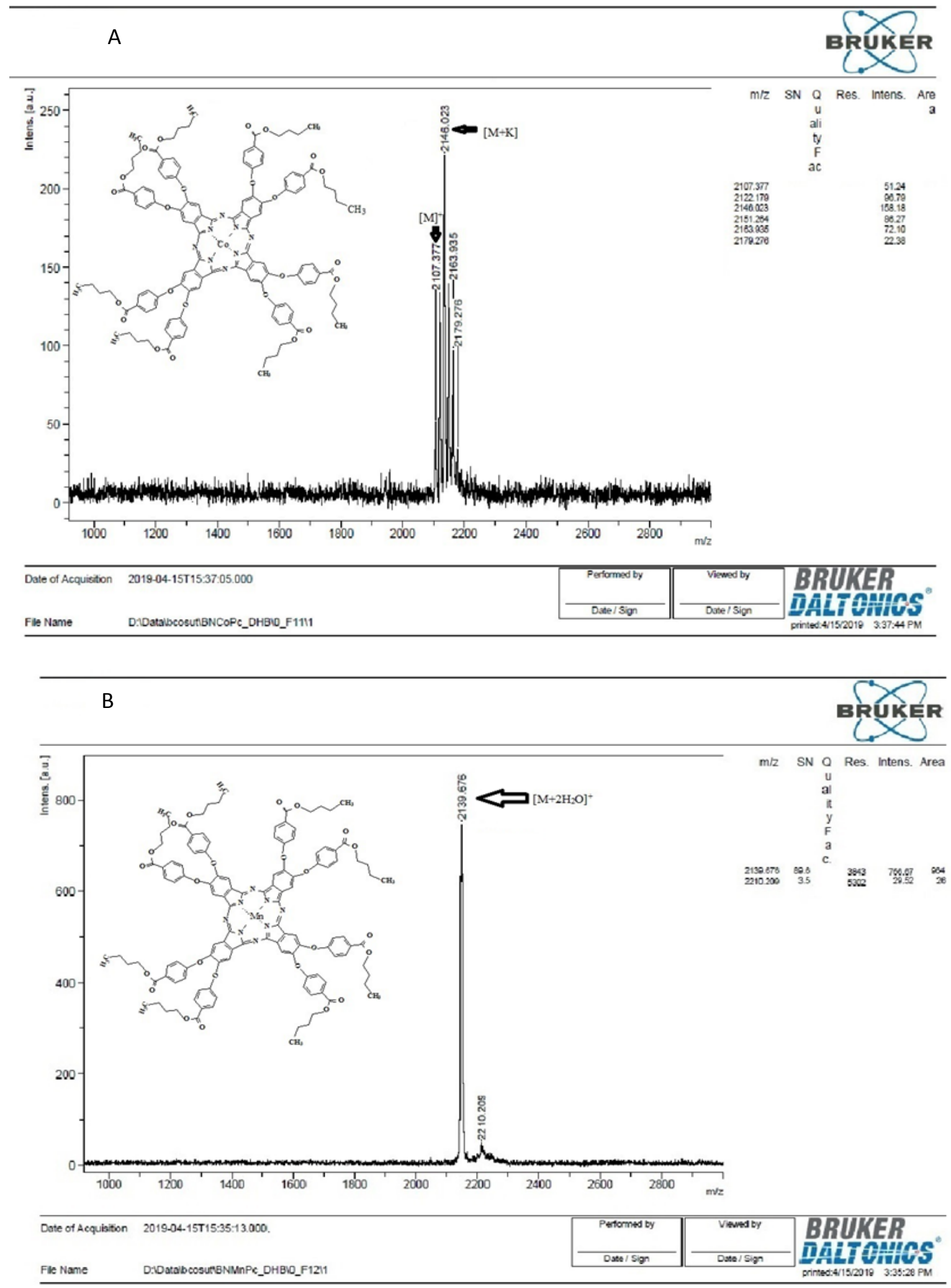

Fig. 3 - The Mass spectrums; A) CoPc, B) MnPc.

In the IR spectrum of MPcs, cyclotetramerization of dinitrile $\mathbf{1}$ to phthalocyanines $\mathbf{2}$ and $\mathbf{3}$ were confirmed by the disappearance of the sharp $-\mathrm{C} \equiv \mathrm{N}$ vibration at $2229 \mathrm{~cm}^{-1} .{ }^{1} \mathrm{H}-\mathrm{NMR}$ spectrum of $\mathbf{2}$ and $\mathbf{3}$ could not be obtained due to paramagnetic nature of the $\mathrm{Co}$ and $\mathrm{Mn}^{32}$

MPcs 2 and 3 displayed typical UV-visible spectra with two significant absorptions, the $\mathrm{Q}$ bands 
in the visible region at about 668 and $725 \mathrm{~nm}$ with the shoulders around 606 and $654 \mathrm{~nm}$, and the B bands at 329 and $383 \mathrm{~nm}$ in the UV region, respectively (Fig. 2). The single Q bands in metal Pcs $\mathbf{2}$ and $\mathbf{3}$ are characteristic for their $D_{4 h}$ symmetry. 33,34

The mass spectrum of compounds $\mathbf{1 - 3}$, at $\mathrm{m} / \mathrm{z}=513[\mathrm{M}+\mathrm{H}]^{+}, 2107[\mathrm{M}]^{+}, 2139\left[\mathrm{M}+2 \mathrm{H}_{2} \mathrm{O}\right]^{+}$ showed molecular ion peaks, respectively providing support for the structure (Fig. 3). The structures; dibutyl4,4'-[(1,2-phenylene)bis(oxy) dibenzoate)]2,3-dicarbonitrile (1), CoPc (2) and $\mathrm{MnPc}(3)$ were also supported by their elemental analysis data.

\section{Aggregation studies}

The aggregation behaviours $\mathrm{CoPc}$ (2) and $\mathrm{MnPc}(3)$ were searched by their UV-Vis spectra recorded at different concentrations (Fig. 4A for compound 2 in THF, Fig. 4B for compound 3 in DMSO). The broad split band and also the presence of a remarkably broad shoulders in $600-660 \mathrm{~nm}$ region at all concentrations within the range of $12 \times 10^{-5}-2.0 \times 10^{-5} \mathrm{M}$ pointed out the presence of $\mathbf{2}$ and $\mathbf{3}$. Although the amount of 2 and 3 relatively decreases with dilution, these species are still present in the solution, even at $2.0 \times 10^{-5} \mathrm{M}$ concentration (Fig. 4). Finally, the compounds 2 and $\mathbf{3}$ didn't show aggregation behaviour in different concentrations (Fig. 4). This is well confirmed by linear variation of the absorption with the concentration, as shown by the spectra in Fig. 4.

The aggregation behavior of $\mathbf{2}$ and $\mathbf{3}$ were also examined in different solvents such as DMF, DMSO, ethyl acetate, chloroform, THF, and toluene (Fig. 5A for compound 2, Fig. 5B for compound 3). The formation of aggregated species at these different solvents was also reflected by the appearance of considerably broad shoulders within the range of $600-660 \mathrm{~nm}$ at a concentration of $1.0 \times 10^{-5} \mathrm{M}$, as shown in Fig. 5. However, the $\mathrm{Q}$ band position slightly changes due to solvent polarity effect, as shown for $\mathbf{2}$ and $\mathbf{3}$ in Fig. 5. In general, the red shift of the $\mathrm{Q}$ band increases with refractive index of the solvent. Compound $\mathbf{2}$ show aggregation in in DMSO and ethyl acetate but the other compound 3 does not form agregated species in all different solvents, as shown by the spectra in Fig. 5 .

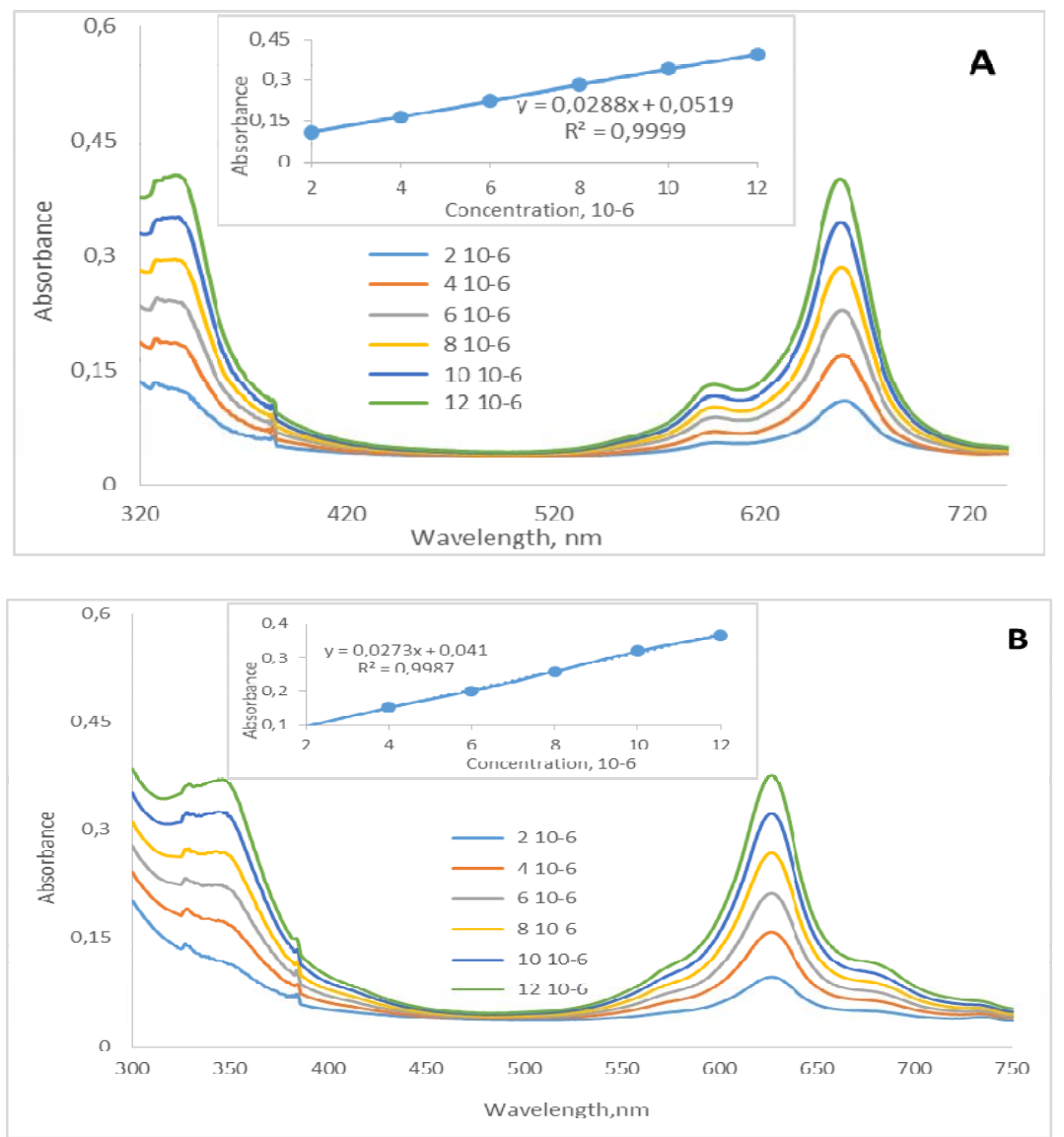

Fig. 4 - The aggregation behaviors of phthalocyanines; A) CoPc in THF, B) MnPc in DMSO at different concentrations. 


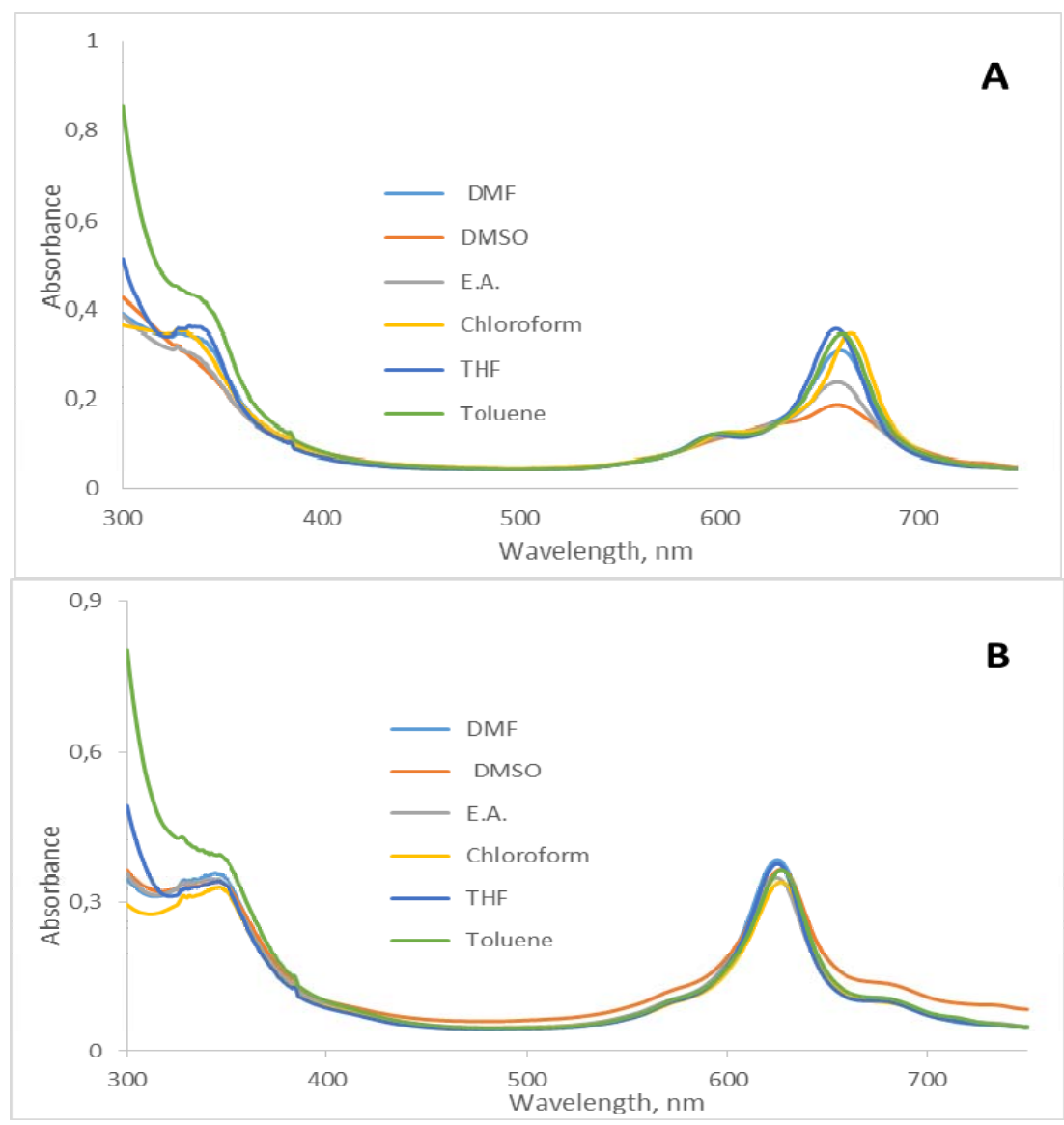

Fig. 5 - The aggregation behavior of phthalocyanine; A) CoPc, B) MnPc in different solvents (1x10 $\left.10^{-5} \mathrm{M}\right)$.

Table 1

In vitro Antibacterial and Antifungal Activity Data of Newly Synthesized Compounds

\begin{tabular}{|c|c|c|c|c|c|c|c|c|c|c|}
\hline \multirow{2}{*}{\multicolumn{2}{|c|}{ Compounds }} & \multicolumn{9}{|c|}{ Microorganisms and Minimal Inhibition Concentration } \\
\hline & & \multicolumn{3}{|c|}{ Gram Positive Bacteria } & \multicolumn{5}{|c|}{ Gram Negative Bacteria } & \multirow{2}{*}{$\frac{\text { Fungus }}{\mathrm{C}}$} \\
\hline No. & Name & B & Sa & Sp & $\mathbf{E}$ & $\mathbf{P a}$ & $\mathbf{P}$ & St & $\mathbf{Y}$ & \\
\hline 1 & $\mathrm{CoPc}(2)$ & 7800 & 7800 & 7800 & 7800 & 7800 & 7800 & 7800 & 7800 & 3900 \\
\hline 2 & $\mathrm{MnPc}(3)$ & 1950 & 3900 & 1950 & 1950 & 1950 & 1950 & 1950 & 1950 & 975 \\
\hline \multicolumn{2}{|r|}{ DMSO } & $\mathrm{N}$ & $\mathrm{N}$ & $\mathrm{N}$ & $\mathrm{N}$ & $\mathrm{N}$ & $\mathrm{N}$ & $\mathrm{N}$ & $\mathrm{N}$ & $\mathrm{N}$ \\
\hline \multicolumn{2}{|r|}{ Amp. } & 100 & 100 & 100 & 100 & 100 & 100 & 100 & 100 & - \\
\hline \multicolumn{2}{|c|}{ Amphotericine B } & - & - & - & - & - & - & - & - & 10 \\
\hline
\end{tabular}

B: B. subtilis ATCC 6633, Sa: S. aureus ATCC 25923, Sp: S. pyogenes ATCC 19615, E: E. coli ATCC 25922, Pa: P. aeruginosa ATCC 27853, St: S. typhymirium ATCC 14028, Y: Y. pseudotuberculosis ATCC 911, P: P. vulgaris ATCC 13315, C: C. albicans ATCC 10231, Amp: ampicilline, AB: Amphotericine B, N: not effected

\section{Anti-microbial and Anti-fungal Activity}

Eight bacteria and one fungus were used to test antimicrobial activities of the newly synthesized 2 and 3 compounds. ${ }^{26-28}$ Ampicillin and amphotericine $\mathrm{B}$ were utilized as standard drugs for comparison of the results (Table 1). The compound 3 was determined more effective than the other compound. The MIC value of compound $\mathbf{3}$ was $1950 \mu \mathrm{g} / \mathrm{mL}$ against all bacteria tested exceptionally $S$. aureus. It was $3900 \mu \mathrm{g} / \mathrm{mL}$. Compound 3 affected against $C$. albicans with MIC value of $975 \mu \mathrm{g} / \mathrm{mL}$. This was the lowest (effective) value of all MIC data in testing. Compound 2 has the MIC value of $7800 \mu \mathrm{g} / \mathrm{mL}$ against all bacteria tested and has the MIC value of 
$3900 \mu \mathrm{g} / \mathrm{mL}$ against the fungus. Compound $\mathbf{3}$ had a broad spectrum of antibacterial activity as it showed significant inhibitory effects on the species of bacteria tested (Table 1). Besides, compound 3 showed antifungal activity against Candida albicans. It has been previously proved in the literature that the isoindole ring in the structure of the compounds play an important role in antimicrobial activity. Tertiary nitrogen of the isoindole ring interacting with the normal cell metabolic processes may role in the formation of a hydrogen bond with the active centers of the cell components, therefore, the mode of action of the compounds might occur. ${ }^{26,-28}$ These results may be important for biological applications.

\section{CONCLUSIONS}

In this study, we have synthesized octasubstituted $\mathbf{2}$ and $\mathbf{3}$, bearing dibutyl4,4'-[(1,2phenylene)bis(oxy)dibenzoate)]2,3-dicarbonitrile moieties at the peripheral position. The structures of new compounds were characterized and characterization results confirmed their proposed structures. The new complexes have good solubility in various organic solvents. Aggregation behaviors of the phthalocyanine were investigated, and only 2 showed aggregation in DMSO and ethyl acetate.

The antibacterial and antifungal activity of $\mathbf{3}$ derivatives varied for the bacterial strains and one fungus tested. Especially, $\mathbf{3}$ showed the best antibacterial activity against all bacteria (exceptionally S. aureus) used in this study with the lowest MIC value. The compound $\mathbf{3}$ is also the most effective to fungus with the lowest MIC value and two times effective than the compound $\mathbf{2}$ for against bacteria and fungus when comparing the phthalocyanine compounds.

Acknowledgements. We are grateful to Dr. Fatih Ş. BERIŞ at Lab of Molecular Biology, Dept. of Biology, Recep Tayyip Erdoğan University, Rize, for help anti-microbial and antifungal activity studies.

\section{REFERENCES}

1. M. Wainwright, "Photosensitizers in biomedicine", Oxford: Wiley, 2009.

2. N. B. McKeown, "Phthalocyanine Materials. Synthesis, structure and function", Cambridge University Press, 1998.

3. S. G. Kimani, T. A. Shmigol, S. Hammond, M. V. Malakhov and J. P. Golding, Photochem. Photobiol, 2013, 89, 139-149.

4. Z. Li, Z. Luo, J. Chen, S. Chen, P. Zhou, P. Xu, J. Hu, N.Way, J. Huang and M. Huang, Bioconjung Chem., 2012, 23, 2168-2172.
5. C. C. Leznoff, A. B. P. Lever and P. Stuzhin (Eds.), "Phthalocyanines properties and applications", $\mathrm{VCH}$ publishers, in New York, 1996.

6. K. Takashi, N. Kuraya, Y. Yamaguchi, T. Komura and K. Murata, Sol. Energy Mater. Sol. Cells, 2000, 61, 403-416.

7. S. Wu, Q. Liu, Y. Zheng and T. Peng, J. Power Sourcers, 2017, 359, 303-310.

8. A. R. Karimi, A. Khodadadi and M. Hadizadeh, RSC Adv., 2016, 6, 91445-91452.

9. J. Sleven, C. Gorller-Walrand and K. Binnemans, Mat. Sci. Eng. C.-Bio S., 2001, 18, 229-234.

10. S. Wu, Q. Liu, Y. Zheng L. Li and Q. Meng, Dyes and Pigments, 2003, 56, 1-6.

11. T. Nyokong, Coord. Chem., 2007, 251, 1707-1722.

12. Ö. Bekaroğlu, Appl. Organomet. Chem., 1996, 10, 605-622.

13. T. Nyokong, Functional Phthalocyanine Molecular Materials, 2010, 135, 45-87.

14. I. Koç, M. Özer, A. R. Özkaya and Ö. Bekaroğlu, Dalton Trans., 2009, 132, 6368-6376.

15. Z. F. Huang, H. W. Bao, Y. Y. Yao, W.Y . Lu and W. X. Chen, Appl. Catal. B., 2014, 154, 36-43.

16. C. C. Leznoff, A. B. P. Lever (Eds.), "Phthalocyanines, Properties and Applications", vol.14, VCH, New York, 1989.

17. M. Özçeşmeci, I. Özçeşmeci and E. Hamuryudan, Polyhedron, 2010, 29, 2710-2715.

18. M. B. Koçak, A. Gürek, A. Gül and Ö Bekaroğlu, Chem. Ber., 1994, 127, 355-358.

19. M. S. Ağırtaş, B. Cabir, A. Dündar, V. Okumuş and G. Ceyhan, Synthesis and Reactivity in Inorganic MetalOrganic and Nano-Metal Chemistry, 2014, 44, 1092-1098.

20. H. Ali, O. St-Jean, J. P. Morin and J. E. Van Lier, Tetrahedron Letters, 2006, 47, 8275-8278.

21. M. T. M. Choi, P. P. S. Li and D. K. P. Ng, Tetrahedron, 2000, 56, 3881-3888.

22. L. Zhang, J. Huang, L. Ren, M. Bai, L. Wu, B. Zhai and X. Zhou, Bioorganic Med. Chem., 2008, 16, 303-312.

23. T. Maisch, S. Hackbarth and J. Regensburger, Jahrhundert J. Dtsch. Dermatol. Ges., 2011, 9, 1-97.

24. S. R. De Annunzio, N. C. S. Costa and R. D. Mezzina, Int J Mol Sci., 2019, 20, 3861-3883.

25. W. L. Armarego, "Purification of laboratory chemicals", Butterworth-Heinemann, 2017.

26. A. Usta, E. Öztürk and F.Ş. Beriş, Natural Product Research: Formerly Natural Product Letters, 2014, 28 483487.

27. E. Menteşe, F. Ş. Beriş and N. Demirbaş, J. Heterocyclic Chem., 2017, 54, 2996-3007.

28. Methods for dilution antimicrobial susceptibility tests for bacteria that grow aerobically; approved standart-tenth edition. CLSI document M07-A10. Wayne, P.A. Clinical and Laboratory Standards Institue; 2015.

29. D. D. Dominguez, A. W. Snow, J. S. Shirk and R. G. S. Pong, J. Porphy. Phthalocyanin., 2001, 25, 582-592.

30. T. M. Michael, P. S. Li Pearl and K. P. Ng. Dennis, Tetrahedron, 2000, 56, 3881-3887.

31. A. Ogunsipe, D. Maree and T. Nyokong, J. Mol. Struct., 2003, 650, 131-140.

32. M. B. Sağlam and A. R. Özkaya, Trans. Metal Chem., 2016, 41, 605-612.

33. A. E. Pullen, C. Faulmann and P. Cassoux, Eur. J. Inorg. Chem., 1999, 1999, 269-276.

34. K. Takahashi, M. Kawashima, Y. Tomita and M. Itoh, Inorg. Chim. Acta., 1995, 232, 69-73. 
